\title{
The empty intersection: why so little public choice in political science?
}

\author{
Randy T. Simmons ${ }^{1} \cdot$ Ryan M. Yonk ${ }^{1}$
}

Received: 13 May 2015/ Accepted: 15 May 2015/Published online: 18 June 2015

(C) Springer Science+Business Media New York 2015

\section{Introduction}

Public choice sits at the intersection of economics and political science. It ought to be easily integrated into introductory courses in each discipline, especially if the instructor is interested in political economy. In this essay we examine whether, and to what extent, public choice principles are taught in introductory political science courses, specifically in the introduction to American government. We find little evidence that public choice has penetrated syllabi and introductory texts and then speculate about why that is the case. We also explain how and why we teach public choice in our own courses.

We are political scientists with strong roots in Virginia Public Choice. As such, we are outliers in our discipline since most political scientists who adopt a rational choice approach, of which public choice is a part, follow the Rochester School of positive political theory and confine their studies to mathematical explanations of political processes. We are more normative in our approach and stick closely to James Buchanan's description of public choice as "politics without romance" (Buchanan 1979).

We teach our courses from the Buchanan perspective. One reason is that our experience tells us that Buchanan, Tullock, and others laid out more than just a set of academic ideas. They actually described how the world we know works. Simmons spent 10 years in city government as a member of a city council and then as mayor. He was an analyst in the U.S. Department of the Interior for 2 years, head of a political science department for 15 years and directs a research institute within a state university. For several years, Yonk co-hosted a drive-time radio program that emphasized analyses of local political issues. $\mathrm{He}$

Ryan M. Yonk

ryan.yonk@usu.edu

Randy T. Simmons

randy.simmons@usu.edu

1 Department of Economics and Finance, Utah State University, 3565 Old Main Hill, Logan, UT 84322-3565, USA 
interviewed local public officials ranging from planning commissioners, to the holders of elective offices, to managers of landfills. He studied local government issues, developing a specialized expertise in their politics. He directed an agency that depended on state funds to provide mental health services, gaining a first-hand education in bureaucratic politics, and like Simmons directs a university-based research institute. We are well versed in the politics of bureaucracy. In addition, we have independently and cooperatively developed strategies and tactics with local and state political campaign operatives. Our experiences with government make us skeptical of positive or even benign views of government. We have experienced the perversities of majority rule, attempts to adopt inefficient policies and redistribute wealth or rights, and the failures of bureaucratic systems. We really do study politics without the romance.

Nearly none of our political science colleagues teach from a public choice perspective. Apparently they never did, as noted by Dow and Munger (1990) as well as Mitchell (1999). Both of those articles concluded that political scientists publishing scholarly journal articles and books did not use their research in classroom discussions.

Why do political scientists not teach public choice in the classroom? The easy and incorrect answer is that political scientists are not trained in ways that prepare them to teach rudimentary public choice in introductory classes. That may have been the case 20 years ago but is surely not the case now. Graduate education in political science has gotten more technical, more mathematical, and more demanding. A doctoral degree in most political science departments looks very much like a degree in an economics department. A more difficult answer that we explore at the end of this essay is that the culture of the profession at large and within the Ivory Tower may be a core cause. We base our claim that nearly none of our colleagues teach public choice in introductory courses in part on a review of the introductory courses taught at the top-ranked departments in the United States. We reviewed syllabi, identified the textbooks used, and then surveyed the textbooks for public choice content.

In reviewing these courses we found a wide variety of texts and approaches to teaching Introduction to American Government. We identified nine texts used by multiple institutions that form the core of our textbook review. We then examined the indexes, tables of

Table 1 Textbooks and public choice presence

\begin{tabular}{ll}
\hline Textbook & Authors \\
\hline $\begin{array}{l}\text { The New American Democracy } \\
\text { The Logic of American Politics }\end{array}$ & Fiorina, Peterson, Johnson, Mayer \\
$\begin{array}{l}\text { Principles and Practice of American Politics: Classic and } \\
\text { Contemporary Readings }\end{array}$ & Kernell, Kousser, Vavreck, Jacobs \\
American Government: Power and Purpose & \\
We the People: An Introduction to American Politics & Lowi, Ginsberg, Shepsle, Ansolabehere \\
$\begin{array}{l}\text { The American Political System } \\
\text { Keeping the Republic: Power and Citizenship in American }\end{array}$ & Ginsberg, Lowi, Weir \\
$\begin{array}{l}\text { Politics } \\
\text { American Democracy: from Founding Theories through }\end{array}$ & Kollman \\
Modern Practices & Stephenson, Turner, Bresler, Friedrich, \\
American Government: Political Development and & Karlesky, Krassa \\
Institutional Change & Jillson \\
\hline
\end{tabular}


contents, and some substantive chapters to look for Public Choice ideas. A list of the texts we considered is provided in Table 1.

Why introduction to American government courses? A few departments, but not most, offer a course that is an introduction to political science and surveys the field-international relations, comparative politics, political theory or philosophy, and American government. The common course across all departments is the Introduction to American Government course. For most departments, it is the default introduction to the field of political science. And for most students (non-majors) who take it, it is their only course in political science because they enroll to fill distribution or general education requirements. We assert that if public choice has affected political science in meaningful and substantial ways it should be evident in these courses and the textbooks required by the instructors.

We needed to decide what concepts to search for and whether they fairly represented the core of public choice. That is, we first had to decide if there is a core to public choice and, if so, what is in it. Our first inclination was to generate a list of terms that show up in our own courses. It did not take us long to compose a massive number of possible search terms that would have made analysis unwieldy at best and, most likely, impossible. We chose instead to rely on Charles K. Rowley's essay "Public Choice: the origins and development of a research program," published in The Elgar Companion to Public Choice, Second Edition (Rowley 2013, pp. 12-38) as an authoritative source of key public choice concepts. Rowley begins the essay by asserting that public choice is "located at the interface between economics and political science" (Rowley 2013, p. 12). So far, so good-if public choice is part of the intersection of the overlapping sets comprised of economics and political science, we would hope to see some public choice in the most basic political science textbooks.

\section{The public choice canon}

Rowley identifies six individual authors and one pair of authors whose work form the foundations of modern public choice: Black (1958), Arrow (1950, 1951), Downs (1957), Riker (1962, 1982), Olson (1965), Niskanen (1971), as the individual authors and Buchanan and Tullock (1962) as the pair of authors. Using Rowley's discussion and description we highlight the ideas from each that should be of core importance to political science and discuss those ideas briefly below. Using our compiled list of the most often used Introduction to American Politics textbooks we considered whether each of the authors' core ideas had penetrated the most basic of political science texts.

\subsection{Vote cycling, the illusion of majority rule, and the public interest is an empty set}

Both Duncan Black and Kenneth Arrow are of particular importance to political science, because they rediscovered and brought into modern consciousness the work of the French noblemen the Compte de Borda and the Marquis de Condorcet. They independently applied mathematical rigor to the question of how much confidence to place in the choices of political decision-making bodies. Specifically, they considered the outcomes of different decision rules when the voting body (of three or more) is considering more than two candidates or policies. Their core insight was to highlight how, depending on the decision rule in place, elections, committee votes, or other collective decision-making processes 
may lead to indeterminate outcomes owing to the cyclical nature of the results. One example of this is highlighted in US congressional votes when a bill is supported by a majority as written, is amended by a majority, and amended bills are defeated despite the bill and amendment having a majority of votes independently.

The vote cycling problem is sometimes referred to as the vote problem, the jury problem, or Condorcet's paradox. Compte de Borda (for whom the solution is named) suggested one possible but imperfect solution, in which voters allocate two votes to the first preference, one to the second, and none to the third, in a three-person race or referendum to solve this problem of vote cycling. ${ }^{1}$

Black rediscovered Condorcet's paradox of cyclical majorities and provided one answer that lies at the heart of much public choice analysis of voting - the median voter theorem. According to the median voter theorem, the optimal strategy for candidates vying for election is to take positions along the (one-dimensional) ideological spectrum so as to capture the voter (who is assumed to be voting sincerely) located at the median of the distribution of voters' preferences and thus maximize the chances of winning. Few ideas are more important to modern studies of political behavior and electoral politics than the core logic of the median voter.

Arrow's interest was in determining whether social welfare functions exist and whether voters, when faced with multiple choices, select outcomes that will yield socially optimal outcomes that are both complete and transitive. From this insight political scientists have developed multiple electoral theories that recognize voting cycles and the impossibility of majority rule determining an unambiguously best outcome. In our own work on this subject we have explored how these issues affect actual electoral decisions. We find, consistent with Arrow's insight that, depending on the voting rules selected, candidates trade places in the final outcome and yet each system has some reasonable claim to being a 'fair' way of determining larger group preferences (Yonk et al. 2010).

Given the key insights of Black and Arrow regarding group decision making, we would expect introductory textbooks that claim to address issues of collective decision making in the United States to include some reference to Black or Arrow. Despite this expectation, we did not find them; nor did we see discussions of the paradox of cyclical majorities, questions about majority rule and best outcomes, or social welfare functions in any of the core texts we reviewed. Concerns about majority rule generally center on two issues. First, on uninformed voters who would (presumably) vote differently if they were better informed or were not misinformed by the influence of money in elections. Second, election rules sometimes restrict access to the franchise for some, especially minority, citizens. A proxy for a social welfare function in textbook language might be "the public interest." Although "the public interest" is raised repeatedly, there is no discussion about the impossibility of making interpersonal utility comparisons and therefore of knowing what the public interest might be. In fact there is often an implicit assumption that the public interest (Rousseau's "will of the people") is obvious. The often non-obvious conclusions from public choice would make these authors and the people teaching from their books uncomfortable and would be inconsistent with the core idea of enlightened democracy and collective decision-making.

\footnotetext{
${ }^{1}$ Condorcet in fact showed that Borda's method is vulnerable to strategic voting; Borda replied that "my scheme is only intended for honest men" (quoted in Rowley 2013, p. 13).
} 


\subsection{Rational self-interest and the median voter}

Among those cited by Rowley as founders of Public Choice, Anthony Downs is the one we believe to be the most cited scholar in political science courses generally. His 1957 book, An Economic Theory of Democracy, introduces a spatial theory of democracy that clearly illustrated the median voter theorem and provides a foundation for most of rational choice explanations in political science. Rowley argues that Downs's biggest contribution, however, was

the introduction of the rational choice approach to the study of political science. Pitting himself against the well-entrenched tradition of behavioral analysis among political scientists, Downs lays the foundation for a major research program that will apply rational choice theory to every aspect of the political marketplace. (Rowley 2013, p. 19)

Downs used the self-interest axiom and spatial theory to explain voting behavior, the convergence of first-past-the-post, single member voting systems to two parties, and the actions of political parties and politicians. From the self-interest axiom he derived his conclusion that politicians act "solely in order to attain the income, prestige, and power which comes from being in office" (Downs 1957, p. 28). Possibly the most famous line from Downs is that "parties formulate policies in order to win elections, rather than win elections to formulate policies" (ibid). Vote-maximizing politicians inhabit the Downsian world, as do utility-maximizing voters and interest groups. In his later book on bureaucracy (Inside Bureaucracy), Downs (1967) introduces the utility-maximizing bureaucrat who seeks advancement and security within bureaucratic structures. Thus, from Downs we get the core actors in public choice theory, vote-seeking politicians, utility seeking voters, favor-seeking interests, and budget-and-security seeking bureaucrats.

The textbooks adopt, implicitly and often explicitly a one-dimensional left-right election space and show politicians moving to the middle in order to win elections. In fact, Hotelling-like movement along the left-right dimension is completely ingrained in political science today. It is an "everyone knows it's true" claim that clearly was not new with Downs. Political reporter Theodore White wrote that, as Barry Goldwater was giving his famous 1964 Republican convention speech, one reporter exclaimed, "My God. He is going to run as Barry Goldwater!" The reporter meant that Goldwater was not going to move to the center in order to capture votes. We doubt that An Economic Theory of Democracy informed the reporter's understanding of movement in the electoral space. But Downs was the first to formalize it and it is now foundational in political science textbooks.

But, the rational actors in the Downsian model do not generally appear in the political science texts. Bureaucrats serve the public interest, as do politicians. Voters think of the public interest when in the voting booth, and interest group politics is a healthy competition that produces invisible-hand-like results. Vote maximizing is seldom discussed in the sections on elections. Strategies and tactics are discussed as ways of achieving votes, but the idea of a politician choosing policies in order to get elected rather than getting elected to pursue policies is absent. Among all of the texts we reviewed, citations and references to Downs's work and theories are generally limited to explanations of his spatial logic and those citations and references were few and far between. 


\subsection{Minimum winning coalitions, strategic voting, and agenda control}

William Riker is the only political scientist in the set of public choice founders. Riker, and the students who followed him, concentrated on coalition formation. In his 1962 book, The Theory of Political Coalitions, he proposed a variation on or even rejection of the Downsian claim that politicians maximize votes. Instead, he suggested that they form "minimal winning coalitions." Politicians, he hypothesized, seek just enough votes to win an election or to achieve a desired policy. In his model, politicians evaluate the costs of winning more votes and stop seeking more when they have enough to win. Seeking more votes simply wastes resources and reduces concessions that must be made as part of the vote seeking process.

Riker's other important book is Liberalism against Populism: A Confrontation Between the Theory of Democracy and the Theory of Social Choice (1982). It is a wonderful exposition of how the discoveries of Condorcet, Borda, Black, Arrow, and Downs can be applied to contemporary democracy. He (1982, p. 168) introduces the concepts of strategic voting and vote trading and demonstrates how they change electoral outcomes and make them "obscure." He explains, "strategic voting renders the meaning of all social choices (vote outcomes) obscure. I emphasize all because we never can know, on any particular outcome, how much or what kind of strategic voting occurred". He also developed the idea of how agenda control determines outcomes. That is, when vote cycling can occur, the person able to establish which alternatives are voted on first determines the outcome. If $\mathrm{A}>\mathrm{B}>\mathrm{C}$ are the agenda-setter's prefernces, then deciding to pit $\mathrm{B}$ against $\mathrm{C}$ in the first round of voting means that $\mathrm{A}$ never gets to be confronted by $\mathrm{C}$, so $\mathrm{A}$ wins simply because of the arbitrary decision to begin voting with $\mathrm{B}$ versus $\mathrm{C}$.

Trading votes across issues (logrolling) is discussed often in the textbooks. The discussion, however, does not place logrolling in the broader context of a theory of minimum winning coalitions. Logrolling is usually viewed as a negative feature of the political process. It is sometimes called "Christmas Treeing" as an analogy for placing enough individually desired ornaments on the legislative tree to get the votes necessary to pass the legislation. Legislators thereby are forced to vote for the entire tree to get their own desired ornaments approved.

In discussions of legislative committees, extended attention often is paid to the powers of committee chairs. Those powers are described, sometimes bemoaned, but not placed in the context of determining outcomes when vote cycling could be present. Agenda setting certainly is not seen as a solution to cycling, as it is by most public choice scholars.

Descriptions of legislative committees are golden opportunities for introducing the concept of strategic voting. We do so in our own courses. Riker's second book contains several examples that are easy and instructive applications classroom use, especially his examples about the era leading up to the Civil War. But we did not often find references to Riker's work or such examples in the textbooks. We think this to be somewhat odd since political scientists clearly understand strategic voting and agenda control, as evidenced by the extended debates they have about voting rules whenever there is a contentious vote in a faculty meeting.

\subsection{Voting rules and tyrannical majorities}

More than a half-century has elapsed since Buchanan's and Tullock's The Calculus of Consent (1962) was published. They extended the analysis of rational self-seeking 
individuals to consider when such individuals will engage voluntarily in collective action. Buchanan and Tullock concluded that collective action is rational as a means of reducing the costs imposed by other individuals pursuing their choices and that the expected costs of collective decision-making are included in the individual's calculus. From these basic assumptions Buchanan and Tullock developed theories about constitutional rules and the processes of constitutional decision making. Like the theorists before them, Buchanan and Tullock are not enamored with simple majority rules. Their emphasis, however, is not on just the irrationality of majority rules as illuminated by Condorcet et al. They emphasize that decisions by majorities can provide incremental benefits to the majority and impose large costs on minorities. In such cases simple majority rules should be rejected. In some cases the only defensible decision rule is unanimity, since that is the only rule that protects minority interests from majorities.

Buchanan and Tullock claim that logrolling across issues can protect minority interests. They thus point to the dangers of tyranny by majorities whenever referendums are held on single issues. In such cases minorities have no protection from the majority-they cannot trade votes over a series of issues as a way of getting some of what they want and are therefore subject to majority opinion. Buchanan and Tullock demonstrate that although logrolling can result in overinvestment in the public sector, a system that allows for vote trading can reduce the inefficiency and losses of simple majority rules. They also show that limiting the domain of politics and introducing more veto points, such as bicameral legislatures and presidential vetoes, provides some protection for individuals and minorities from majority exploitation. One conclusion from The Calculus of Consent is that democracy is dangerous.

Political science textbook authors do not claim that democracy is inherently dangerous. They do claim that a restricted franchise and elite power threaten the promise of democracy. We use "promise of democracy" to summarize the nearly unbridled enthusiasm for democratic processes that is inherent in the books we reviewed. Rather than recognizing the pitfalls of majority rule, rationally ignorant voters, agenda control and tyrannical majorities, they celebrate the idea of democracy.

\subsection{The logic of collective action}

Mancur Olson exploded standard theories of interest group actions, many of which continue to be part of political science courses. In his The Logic of Collective Action, Olson (1965) applied a rational choice approach to interest groups. Downs had already provided the basis for such an application, but it was not fleshed out until Olson. Traditional group theory assumed that people join interest groups and work to advance the group's interest because of shared goals. Olson, however, pointed out that group members often get the benefits of group action even if they do not contribute to that action. In such cases, it is irrational to participate or contribute. Thus he suggested that public goods are difficult to provide privately and that groups will not organize spontaneously to act in group members' interests. He argued therefore that political entrepreneurship is necessary to organize selective benefits or punishments to get people to join groups and contribute to their time and money to the group's cause. He showed that it is easier to organize small groups than large ones, leading to the conclusion that in politics small wellorganized groups can exploit large unorganized ones. Examples of this abound and have been discussed seriously by political scientists. From the explicitly political, i.e., political action committees, to the more mundane requirements for professional licensure of hairdressers, political scientists have relied on Olsen's logic.

We find, however, that the textbooks we examined primarily use sociological concepts about interest group formation and actions. Concern is raised about the unorganized 
without considering why they are unorganized. The authors clearly understand that small well-organized groups can exploit large unorganized ones. But they do not provide an analytical framework for understanding group formation, functions, and effectiveness.

\subsection{Hardworking bureaucrats in non-working bureaucracies}

Niskanen rounds out the foundational theorists of public choice. His Bureaucracy and Representative Government (1971) was a frontal assault on the theories of public administration that had existed at least since Woodrow Wilson and Max Weber and which were based on a belief that bureaucracies pursued the public interest and that exalted "public service" untainted by politics as a vocational calling. Niskanen hypothesized that bureaucrats are just as self-seeking as the rest of us. Since bureaucrats are not residual claimants - they do not gain the profits or pay the costs of their actions- they maximize on other margins. They pursue, according to Niskanen, job security, status, and power, which are most easily accomplished by protecting and increasing agency budgets. The simplest conclusion from Niskanen is that at least senior bureaucrats are budget maximizers, especially maximizers of discretionary budgets. Lower level bureaucrats respond to incentives within the agency to protect their own status and security. The choices by bureaucrats at all levels may often be contrary to some definition of public interest, especially contrary to efficiency. Rowley's essay cites a review by itchell in the 1974 American Political Science Review of Bureaucracy and Representative Government. It is useful to quote Mitchell as it provides some guidance to the analysis that follows:

One does not always expect 'wisdom' in more or less technical expositions, but somehow Niskanen provides readers and especially classroom teachers with some highly quotable observations. Two that appeal to me ... are the claim that 'the most dangerous of all politicians is one who is indifferent to his own reelection or the future of his party' and the play on Adam Smith— 'There is an "invisible hand" in government but it is a helping hand for some, a barely acceptable appendage to many, and a mailed fist for others.'

Mitchell was a political scientist, one of the very few Virginia Public Choice political scientists. Because he understood very well the foundational concepts of public choice, he was drawn to Niskanen's analysis. But the authors of the introductory textbooks are not similarly attracted. Although statements like the following are typical in the bureaucracy sections of the textbooks, they are just statements without any follow-up analysis: The acquisitive model of democracy is "A model of bureaucracy that views top level bureaucrats as seeking to expand the size of their budgets and staffs to gain greater power" (Bardes et al. 2013, p. 388). That sentence was the only Niskanen-like passage in the entire section on bureaucracy. There was, as is typical, a long discussion about the structure of bureaucracies and of the civil service system and of bureaucrats as public servants.

\section{Why so little public choice?}

Teaching public choice in a political science department is challenging. Political scientists tend to begin their studies of politics from a much different perspective than do public choice theorists. The following descriptions of difficulties of teaching public choice in 
introductory political science courses will illustrate. We begin with our view of the state of political science.

Unlike economics, political science has no central, agreed-upon tenets about approach, methodology, or even assumptions about human nature. University of Oregon political scientist Orbell (2010, pp. 1-2) provides a clear-eyed description of the discipline:

I don't see it as a discipline in the sense of, say, economics, where scholars frequently agree on theory and methodology; political science is more a holding company for people interested in subjects that, by some stretch of the imagination, can be called "politics." Understandably, this cacophony can sometimes lead to departmental conflict, but it can also disappear if one side wins all the hiring battles.

The once-dominant approach that continues to characterize some of political science is thick description, which is to organize mountains of information about the workings of government in an attempt to describe the political world. The result is narrative, not analysis. But description without theory yields few testable hypotheses or even useful conclusions. For example someone may describe in great detail the powers of Speakers of Houses of Representatives at state or national levels and assert that Speakers are "too powerful." But that conclusion fails to account for how or why power is centralized or the effects of decentralization. It is simply an opinion unsupported by analysis. This tradition continues in most political science departments under the title of functional or institutional theory.

Other political scientists develop theories of government as a forum for resolving conflicts between competing interests. Their solution to some interests prevailing over others is to get more interests represented in government - that is, expand the set of "stakeholders". Still others see government as a system of elite rule in which the elite's excesses can be controlled by strict political rules. If there is a prevalent view about government among political scientists it is that government is generally benevolent and seldom dangerous. As Simmons has written elsewhere,

To them, politics is where values are resolved, inequalities narrowed, inequities solved. According to some, participating in politics is noble. The state builds character and creates civic and personal virtues. Most political scientists' faith in government is matched with skepticism about markets, skepticism fueled by the market failure literature and, for some, even rooted in a longing for market socialism. (Simmons 2012, p. 2)

If there is a dominant approach today it is behaviorism: an approach grounded in measurement and analysis. Public opinion polling is a typical tool used by behaviorists as they seek to examine the behavior or actions of individuals. They are more interested in human actions than in institutions. The behavioral revolution, as it came to be called, purported to infuse political science with a scientific methodology that would allow explanation and prediction. It especially attempted to differentiate facts from values. Behaviorists claim that their statistical techniques reduce the biases inherent in descriptive and philosophical analyses.

One other and much newer tradition in political science is rational or social choice, which was developed at the University of Rochester. It begins with methodological individualism and borrows the rationality assumption from economics. Rational choice political scientists have concentrated their efforts on interest groups, elections, coalitions, and legislatures. Game theory is a cornerstone of much modern rational choice analysis. The other modes of analysis in political science were relatively reader-friendly, but rational 
choice theory is not. Working one's way through a rational choice research paper can be challenging and even impossible for someone who has little mathematical background. Even so, articles based on the mathematically intense methodology of rational choice analysis currently dominate the major academic journals in political science.

A great deal of tension is evident in political science departments over methods and assumptions. We know of one department that was divided between the "Prussians" and the "Mushies." These names were used by the graduate students to describe the faculty. Prussians were the behaviorists and rational choice theorists-they used numbers and computers. Mushies were political philosophers, joined by the functionalists and institutional theorists whose work was normative and descriptive. While this example is anecdotal, it is consistent with the ongoing "Perestroika" movement inside the American Political Science Association. The original email that sparked the movement was from an anonymous "Mr. Perestroika" and it attacked the American Political Science Review for emphasizing mathematical modeling by "poor game theorists" and "failed economists" (Stewart 2003). This division may seem extreme to people not familiar with political science departments, but it is consistent with those we know. A further division occurs over visions of the state. Rousseau and Marx continue to compete with Locke, Smith, and Hume in everyday departmental conversations and in the organization of voting blocs. In our experience, the most important and first question political science faculty ask about a potential new colleague is whether or not the candidate supports one's world view. As Orbell (2010) noted in his description of political science, who gets to do the hiring matters a lot.

One might think that the lack of a central coherence to political science and even deep divisions within the discipline would provide an opportunity for public choice to enter the political science teaching space. That has not been the case, especially at the introductory level. Instead that space has become occupied by introductory texts that are little more than (somewhat) advanced high-school civics textbooks.

Every political science department in the United States offers an introductory course in American politics. It often serves as the first course in the field for political science majors and in many states it is required by legislative decree. Several different members of the department, regardless of whether they are Prussians or Mushies, generally teach different sections of the same course. One way to resolve differences over course content is to teach from textbooks that do not threaten the worldviews of the different individuals and coalitions within a department. These textbooks are well written, informative, and some are even entertaining. They rely on the old approach to political science of thick description, describing the institutions and actors in American politics, while offering few analytical tools for evaluating political processes and outcomes. Politicians generally are assumed to seek office to promote their visions of the public good. Public interest groups work for the public interest while private interest groups are suspect and even denigrated. Bureaucrats are effective yet maligned public servants. Government could do far more good if it was allowed to and democracy is unambiguously good. The measure of the health of a democracy is the proportion of people voting.

Public choice challenges the civics approach and all of the conclusions drawn from it. There is little room in the introductory course curriculum for the challenges raised by public choice. Moreover, no demand exists for a textbook based on public choice reasoning. Two excellent introductory public choice textbooks once were available for adoption. Mitchell published a 1971 textbook titled Public Choice in America: An Introduction to American Government (Markham Publishing Company). A second edition never was written. In 1981, Peter Aranson published American Government: Strategy and 
Choice. Like Mitchell's text, too few instructors adopted it to justify a second edition. Used booksellers continue to make a few copies available. The only other public choice textbook of which we know was Frances's (1976) American Politics: Analysis of Choice. We could not find it available from any of the sellers of used books.

\section{Conclusions}

If an enterprising professor wants to teach public choice in his or her introduction to American government classroom, little is available that is appropriate for that level. Beyond Politics by Simmons (2012) is a good review of public choice theory and applications, but is pitched more to upper division students than to freshman, Similarly Shepsle's (2010) Analyzing Politics: Rationality, Behavior and Institutions can be used in lower division classes, but we believe it is more suited to upperclassmen. Shughart (2015) explains that he uses Shepsle in his public choice course for advanced undergraduates and M.A. students, which is taught in an economics, not a political science department.

Despite the foregoing, introducing American government is an excellent place to teach public choice concepts. In our own introductory courses we begin with homo economicus and homo politicus and then proceed to explore American government from the founders to today. Starting from this public choice perspective, students intuitively grasp vote maximizing, bureaucratic self-interest, interest group strategies, and rationally ignorant voters. Those concepts allow students to analyze and understand politics. They also give students the tools to be critical readers of their assigned textbooks.

\section{References}

Aranson, P. H. (1981). American government: Strategy and choice. Cambridge: Winthrop Publishers.

Arrow, K. J. ([1950] 1983). A difficulty in the concept of social welfare. In The collected papers of Kenneth J. Arrow: Social choice and justice (Vol. 1). Cambridge, MA: Belknap Press of Harvard University Press.

Arrow, K. J. ([1951] 1963). Social choice and individual values (2nd ed.). New Haven, CT: Easton Press.

Barbour, C., \& Wright, G. C. (2013). Keeping the republic: Power and citizenship in American politics (6th ed.). Thousand Oaks, CA: CQ Press.

Bardes, B. A., Shelley, M. C., \& Schmidt, S. W. (2013). American government and politics today: Essentials. 2013-2014 ed. Boston: Wadsworth, Cengage Learning.

Black, D. ([1958] 1987). The theory of committees and elections. Boston: Kluwer Academic Publishers.

Bresler, R., Turner, C., Stephenson, D. G., Karlesky, J., Friedrich, R., \& Kassa, M. A. (2013). American democracy: From founding theories through modern practices (6th ed.). Redding, CA: BVT Publishing.

Buchanan, J. (1979). Politics without romance: A sketch of the positive public choice theory and its implications. Inaugural Lecture, Institute for Advanced Studies, Vienna, Austria, IHS Journal, Zeitschrift des Instituts fur Hohere Studien 3, B1-B11.

Buchanan, James M., \& Tullock, Gordon. (1962). The calculus of consent: Logical foundations of constitutional democracy. Ann Arbor, MI: University of Michigan Press.

Dow, Jay K., \& Munger, Michael. (1990). Public choice in political science: We don't teach it, but we publish it. P.S. Political Science and Politics, 23(4), 604-609.

Downs, Anthony. (1957). An economic theory of democracy. New York: Harper and Row, Publishing Inc.

Downs, Anthony. (1967). Inside bureaucracy. New York: Little, Brown and Company.

Fiorina, M. P., Peterson, P. E., Johnson, B. D., \& Mayer, W. G. (2011). The new American democracy, alternate edition (7th ed.). Boston: Pearson.

Frances, Wayne. (1976). American politics: Analysis of choice. Culver City: Goodyear.

Ginsberg, B., Lowi, T. J., \& Weir, M. (2008). We the people: An introduction to American politics (7th ed.). New York: W. W. Norton \& Company Inc. 
Jillson, C. (2011). American government: Political development and institutional change (6th ed.). New York: Routledge.

Kernell, S., Kousser, T., Vavreck, L., \& Jacobs, G. C. (2013). The logic of American politics (6th ed.). Thousand Oaks, CA: CQ Press.

Kernell, S., \& Smith, S. S. (2012). Principles and practice of American politics: Classic and contemporary readings (5th ed.). Thousand Oaks, CA: CQ Press.

Kollman, K. (2011). The American political system. New York: W. W. Norton \& Company Inc.

Lowi, T. J., Ginsberg, B., Shepsle, K. A., \& Ansolabehere, S. (2012). American government: Power and purpose. brief (12th ed.). New York: W. W. Norton \& Company Inc.

Mitchell, W. C. (1971). Public choice in America: An introduction to American government. Markham, ON: Markham Publishing Company.

Mitchell, William C. (1974). "Bureaucracy and Representative Government" review of Bureaucracy and Representative Government, by William A. Niskanen. The American Political Science Review, 68(4), 1775-1777.

Mitchell, William C. (1999). Political science and public choice: 1995-70. Public Choice, 98, 237-249.

Niskanen, W. A, Jr. (1971). Bureaucracy and representative government. Chicago \& New York: AldineAtherton Inc.

Olson, Mancur. (1965). The logic of collective action. Cambridge: Harvard University Press.

Orbell, J., Fall. 2010. Reflections on a privileged life. In Political science. Oregon: Department of Political Science, University of Oregon.

Riker, W. (1962). The theory of political coalitions. New Haven: Yale University Press.

Riker, W. (1982). Liberalism against populism: A confrontation between the theory of democracy and the theory of social choice. Long Grove, IL: Waveland Press Inc.

Rowley, C. K. (2013). Public choice: the origins and development of a research program. In M. Reksulak, L. Razzolini \& W. F. Shughart II (Eds.), The Elgar companion to public choice (2nd ed., pp. 12-38). Northampton, MA: Edward Elgar Publishing, Inc. (Originally published in C. Rowley \& F. Schneider (Eds.), The encyclopedia of public choice, Vol. 1 Dordrecht, Kluwer Academic Publishers, 2004).

Shepsle, K. (2010). Analyzing politics: Rationality, behavior and institutions. New York: W. W. Norton \& Company.

Shughart, W. F. (2015). Teaching public choice at the master's level. Journal of Economics and Finance Education, 14(2), 5-22.

Simmons, R. T. (2012). Beyond politics: The roots of government failure. Oakland: The Independent Institute.

Stephenson, G, Jr, CC, Turner, Bresler, R. J., Friedrich, R. J., Karlesky, J. J., \& Krassa, M. A. (2013). American democracy: From founding theories through modern practices (6th ed.). Redding, CA: BVT Publishing.

Stewart, S. A. (2003). Revolution from within. University of Chicago Magazine, 95, 5. Retrieved July 30, 2003, from http://magazine.uchicago.edu/0306/features/index-print.shtml.

Yonk, R. M., Simmons, R. T., \& Johnson, D. G. (2010). Trading places. Public Choice, 146(3-4), P341P351. 